\title{
WILLIAM RITCHIE
}

The name of William Ritchie, who died on February 7, 1945, will always be associated with the recognition of Auricular Flutter: forty years ago, on June 23, 1905, he recorded clear auricular waves at a rate of 274 to the minute in a venous tracing from the jugular vein of a case of heart block. Thereafter in many papers he established its clinical and instrumental recognition, and suggested the name of auricular flutter.

Born in Edinburgh on November 5, 1873, Ritchie received his early education at Edinburgh Academy, and graduated in medicine in 1896 as M.B., C.M. of the University of Edinburgh. At school and at the university he was a contemporary of Edwin Bramwell, whose sympathetic memoir in the Edinburgh Medical Journal recalls the chief incidents in Ritchie's life. They both graduated on the same day, and enjoyed a lifelong friendship. From his student days it was, apparently, recognized that Ritchie had the capabilities for making a name for himself in medicine. He was also a keen football player, and for many years played forward for the Edinburgh Academicals.

After qualification he was house physician to Dr. Affleck at the Royal Infirmary, Edinburgh, and afterwards served as house surgeon to Mr. Pringle in Glasgow. Following these house appointments, he went to Vienna for some months, learned German, and came under the influence of Wenckebach. On his return to Edinburgh he did some bacteriological research in the laboratory of the Royal College of Physicians, and in 1900 published a paper on the bacteriology of bronchitis. From 1900 to 1905 he worked in Dr. George A. Gibson's wards as Clinical Tutor. There is no doubt that Gibson's influence and the opportunities in his wards stimulated Ritchie's interest in cardiovascular diseases. It was through Gibson's influence that a laboratory for clinical research was instituted in the Royal Infirmary. Ritchie's entry into medicine coincided with the enthusiastic adoption of Mackenzie's methods of graphic representation of irregularities of the heart beat, and Ritchie was one of Mackenzie's first disciples. He was also one of the first to work with Einthoven's string galvonometer.

Ritchie took the Membership of the Royal College of Physicians, Edinburgh, in 1900, and was elected a Fellow in 1903. In 1905, in recognition of his work on cardiovascular disease, he was elected a Fellow of the Royal Society of Edinburgh. At this time he was gaining considerable experience in the post-mortem room as pathologist to the Leith Hospital from 1902 to 1906, and from 1906 to 1910 he was Assistant Pathologist at the Royal Infirmary. In 1911 he was appointed Assistant Physician to the Royal Infirmary. During these years he published papers on heart block, both on his own account and with Dr. George Gibson, and together they published a historical instance of the Stokes-Adams syndrome in 1909. In 1911 Jolly and Ritchie published a very comprehensive account of auricular flutter and fibrillation in Heart (Vol. II, 1910-11). It was Ritchie who gave the name of auricular flutter to the rapid co-ordinate contractions of the auricles. He was well aware that MacWilliam had produced similar rapid co-ordinate contractions by faradizing the auricles in cats and dogs which he described as a rapid flutter (1887). Ritchie and the writer of this memoir spent three days with MacWilliam in 1909 when he showed us his methods of producing both flutter and fibrillation. MacWilliam at this time was also interested in the subject of blood pressure, and he had a large artificial schema of the circulation in his laboratory. In 1913 Ritchie became Physician to the Deaconess Hospital, and in 1914 published his book on Auricular Flutter, and included a record of all the then-known cases.

In the spring of 1914 Ritchie and the writer spent ten days in Düsseldorf, Cologne, and Bonn. Two non-medical episodes stand out in my mind; we stood in the middle of the Hohenzollern Bridge in Cologne and looked at the new Hindenburg Bridge rather higher up the river, which was not yet opened, and speculated that the reason of its building was for the conveyance of troops. We spent another day with Professor Verworn, the physiologist at Bonn University, and as we passed through the rooms of his private house we kept picking up and admiring military dolls from the various chairs and settees, and Verworn remarked that 
the whole country was talking about war. He told us, also, that he spent part of his summer vacation with his family at an English watering place, and on leaving him we suggested that at his next visit he might be inclined to visit our medical schools.

When war came in August 1914 Ritchie was called up on the staff at the 2nd Scottish Hospital as Captain R.A.M.C.(T.), but being determined to see active service he joined the $1 / 3$ rd Scottish Horse and found himself with his squadron in the Newcastle area, and during his sojourn in this district he spent much time in the Newcastle Infirmary. He went with the Scottish Horse to Gallipoli, and wrote many interesting letters of his experiences on the Peninsula. Later he was in charge of the Medical Division of the 27th General Hospital in Egypt, where he remained to the end of the war. He was mentioned in despatches and awarded the O.B.E., and in 1920 he published (jointly) a review of heart cases in the E.E.F. (1916-1918). While in Egypt he met his future wife, whom he married shortly after the war.

In 1919 Ritchie returned to Edinburgh and resumed his hospital work and consulting practice in Edinburgh, and in 1922 he was appointed full Physician to the Royal Infirmary, and became Principal Medical Officer of the Edinburgh Insurance Company.

As adviser to the Ministry of Pensions he organized the post-war disposal of V.D.H. and D.A.H. cases in the east of Scotland. Similar advisers in regions of England and the west of Scotland used to meet twice a year at the Ministry of Pensions for some years after the war, and it was this company of friends, interested in the same sort of work, who decided in 1922 to start the Cardiac Club when the meetings under the auspices of the Ministry of Pensions ceased. Ritchie was one of the keenest members, and acted as Treasurer from its commencement to 1931.

In 1928 Ritchie succeeded Professor Gulland as Professor of Medicine, and reorganized the systematic teaching of medicine, retiring from the University Chair in 1937. He held office as President of the Royal College of Physicians from 1935 to 1937, and in 1923 and 1935 he collaborated with his friend John Cowan in the 2nd and 3rd editions of Cowan's book Diseases of the Heart. Throughout his professional life he maintained constant touch and friendship with John Cowan of Glasgow. Ritchie gave the Gibson Memorial Lecture in 1922 on "The Response of the Heart in Health and Disease," and in 1939 the St. Cyres Lecture, taking as his subject " Rheumatic Heart Disease."

At the outset of this war Ritchie took over temporary charge of the wards of an absent colleague at the Royal Infirmary, and was made Physician to the Emergency Medical Hospital at Bangour, so that he continued his ward teaching to the end of his days.

A year before he died the University of Edinburgh conferred upon him the honorary degree of LL.D.

Ritchie gave to Edinburgh the knowledge of the cardiovascular system which the work of G. A. Gibson, Mackenzie, Lewis, and Wenckebach had made possible, and to this knowledge Ritchie made valuable additions. From 1905 to 1913 he published at least twenty contributions on cardiovascular disease, and they all included his own personal work and observations. Far into the night he puzzled over and analysed polygraph tracings and electrocardiograms. The mechanism of the heart beat was being elucidated by many workers, and the early collection of records of heart block, auricular flutter and fibrillation, paroxysmal tachycardia, and the extrasystole was a fascinating pursuit. All Ritchie's work in these fields was characterized by scrupulous care.

As a ward teacher and an academic lecturer Ritchie never lost sight of the essential facts of clinical medicine and his knowledge was not confined only to disorders of the cardiovascular system. As an examiner he was somewhat frightening, but again scrupulously fair.

He was a somewhat shy person and never played to the gallery, and, as Edwin Bramwell has said, " his best qualities were not on the surface." His austerity was only equalled by his sincerity. His Promoter's address to the graduates at the Graduation Ceremonial on July 22, 1936, set forth his " Philosophy of a Doctor." It ended with these words, " May the story ultimately to be told of each of you be one that is abiding everywhere without visible symbol, woven into the stuff of other men's lives." Ritchie's high principles and conscientious work must have been woven into the lives of many generations of Edinburgh students.

W. E. Hume. 